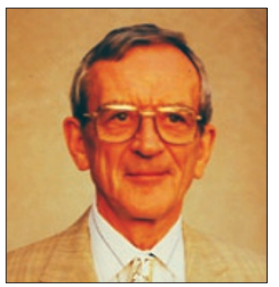

\title{
Edward A. Boyse
}

\section{3-2007}

Judith Bard, Gary K Beauchamp \& Ellen H Goldberg

Edward A. Boyse, who established the fields of cell-surface immunogenetics, odor-type genetics and cord-blood transplantation, died on 14 July in Tucson, Arizona. He was 83 . Boyse was the first individual to be elected to full membership of The Royal Society, the American Academy of Arts and Sciences, and the US National Academy of Sciences, and, since 1947, the only recipient of the prestigious Isaac Adler Prize awarded jointly by Harvard and Rockefeller Universities.

Boyse's first training was in the air. He joined the Royal Air Force in 1941 at the age of $171 / 2$, the youngest age of intake, and served throughout World War II, demobilizing in 1946 with the rank of flight lieutenant. Flying remained his passion, and he often recalled a particular fondness for tunneling in clouds ("First you have to make sure nobody else has borrowed that cloud"). Later in life he returned to the air by skydiving and building ultralight aircraft with friends and family.

A diffident man, Boyse maintained that he took up medicine because there was nothing else he was able to do, a fallacy of which he could not be disabused. He attended the University of London, graduating MB, BS in 1952 and MD in 1957. His thesis, on the spread of herpesvirus in the cerebrospinal fluid of the rabbit, was undertaken in the laboratory of George Payling-Wright, at Guy's Hospital in London. Boyse retained a lifelong affection for Payling-Wright, whose excuse for lateness he delighted in quoting: "Sorry I'm late, Boyse, a combination of sloth and loquacity." It was a genial place.

After a brief stint in patient care and an equally unwelcome period in the Public Health Laboratory Service, Boyse joined Peter Gorer at Guy's, at a time when the H-2 major histocompatibility complex in mice was first being identified and refined. Boyse credited many of his subsequent avenues of thought and exploration to his grounding in Gorer's lab and its cordial rivalry with Sir Peter Medawar's lab not too far distant.

In 1960, Boyse took up his first appointment in the United States, at New York University School of Medicine's Department of Pathology, an institution that then hosted Baruj Benacerraf. It was at NYU that Boyse began breeding his genetically defined congenic mouse colonies. These mice, and the antisera (and later monoclonal antibodies) that they produced and that Boyse shared freely with any investigator sufficiently stalwart in requesting them, became the cornerstones of worldwide immunogenetic programs, as did his improved materials and techniques for the conduct of reliable serology.

Boyse moved to the Sloan-Kettering Institute (SKI) for Cancer Research in 1964, formalizing an arrangement that had been de facto for some time before that. The move was facilitated by Benacerraf, whose intellectual and professional generosity Boyse held in the highest esteem. SloanKettering offered many attractions to Boyse, not least of which were a lack of formal teaching obligations, a relatively unfettering administration and

Judith Bard is in the Department of Immunobiology, University of Arizona, Tucson, Arizona, USA. Gary K. Beauchamp is at the Monell Chemical Senses Center, Philadelphia, Pennsylvania, USA. Ellen H. Goldberg is president emeritus of the Santa Fe Institute and a research professor in the Department of Biology, University of New Mexico, Santa Fe, New Mexico, USA. e-mail: judithbard@comcast.net adequate, autonomous quarters for his animal colonies. Of particular pride to Boyse was the development of the staff of his Congenic Mouse Production Facility, many of whom had originated from underprivileged backgrounds and who became expert, under his guidance, in all aspects of animal husbandry and rigorous genetic in-line breeding.

Thus settled at SKI, Boyse developed the series of collaborations that came to define his style of research. In classical serological immunogenetics, Boyse, working primarily with Lloyd Old in the 1960s and Harvey Cantor in the 1970s, identified numerous components on the surfaces of cells of the immune system. This was achieved by undertaking the most painstaking series of reciprocal immunizations to generate and then define the alloantibodies thus produced. One of the most talented of Boyse's postdoctoral fellows engaged in this program was Fung-Win Shen, whose untimely death, in 1995, is still lamented.

Most notable among the molecules defined were the Ly system of antigens, which were found to hallmark functionally distinct subclasses of lymphocytes. Now known as CD4 and CD8, these systems are universally familiar, and it may be that their origin has passed from the common consciousness.

Boyse was particularly engaged by the definition of weak histocompatibility antigens. Years before, Medawar had conducted a famous series of experiments showing that an irradiated mouse reconstituted with H-2-compatible bone marrow would accept skin grafts from the bonemarrow donor. In some cases, however, skin-graft rejection was observed at about 100 days, too long an interval to be attributable to the $\mathrm{H}-2$ major histocompatibility complex. Because no weak antigens had then been recognized, Medawar proposed the term 'split tolerance', a nebulous term, and theory, that offended Boyse's biological sensibilities. The Skn system, originally identified by Margrit Scheid-a research associate in Boyse's lab and subsequently, with Boyse's wholehearted approval, head of an independent lab — was his irrefutable counter. Graduate student Ellen Goldberg pursued this line of investigation. She found that Skn was an alloantigenic system expressed selectively on epidermal cells of the skin and brain, and was responsible for late-stage skin-graft rejection by mice that had received bone marrow from a donor with an identical $\mathrm{H}-2$ type. How much of Boyse's satisfaction was due to the earlier Gorer-Medawar rivalry remains a matter for speculation.

Another cell-surface component, and weak histocompatibility antigen, described during this period was the H-Y system, expressed by male but not female cells of all mammalian species. Always somewhat controversial, $\mathrm{H}-\mathrm{Y}$ was at one time considered a candidate for the primary determinant of male sex, and some moderate success was achieved with $\mathrm{H}-\mathrm{Y}$ in the serological sex-selection of embryos. This program was conducted by Stephen Wachtel, whom Boyse had invited to join the lab upon discovering, among his other qualifications, that he had been a US Air Force pilot, and was, by virtue of training, a third-generation skin-grafter from the Medawar-Billingham 'legitimacy'.

The list of immunogenetic systems described by Boyse is not short, and yet was just one aspect of his multifaceted interests and programs.

In the early 1970s, while conducting crosses in the breeding of a congenic strain of mice, two members of the staff of the congenic mouse 
production facility, Jeanette Boyse, then married to Boyse, and Tony Zayas noticed that male mice preferred to mate with a female who carried a different H-2 type from their own. At about the same time, and independently, Lewis Thomas, then president of Memorial SloanKettering Cancer Center, noted in one of his essays that dogs might be used to "sniff out our histocompatibility types." Controlled mating trials established that the H-2 major histocompatibility complex was responsible for preferential mating in mice. Kunio Yamazaki, a visiting investigator from Japan, was given supervision of these labor-intensive trials. When it was suspected that the mode of recognition in this assortative mating was mediated by the olfactory system, Boyse approached the Monell Chemical Senses Center, the largest institution in the world devoted to the study of taste and smell. Boyse engaged the enthusiastic interest of Gary Beauchamp, then a young investigator and now president and director of Monell. Eventually the physical conduct of the program, together with its staff, migrated to Monell owing to the more appropriate environment there. Boyse retained a special interest in this field, which has now become densely populated, and he developed a close personal friendship with Beauchamp, which encompassed, inter alia, rare books and derelict buildings.

That Boyse was willing to see the departure of a program as farreaching as odor-type genetics is just one example of his scientific altruism: what was best for the program was what prevailed. He was equally generous in sharing his thoughts and hypotheses with others. He especially appreciated the series of Japanese visiting investigators who rotated through his lab, each of whom took back to Japan, in addition to first-rate publications, something of the culture of the Boyse lab, which included open collaborations and avoidance of speaking engagements.

Cord-blood preservation and transplantation, now in worldwide practice, is another example of Boyse's originality. It is a tribute to Boyse that colleagues and friends who expressed dismay that this program no longer receives appropriate attribution were told: success has many fathers; failure is an orphan. Paternity in this case, however, is clear. It was Boyse who proposed that umbilical cord blood could be used in place of bone marrow for hematopoietic reconstitution, and should therefore be preserved, particularly for use by the donor individual.

Boyse, together with his associate and partner, Judith Bard, later his wife, conducted the experiments in mice, secured the initial funding and assembled the team that was responsible for the first successful clinical umbilical-cord blood transplant. The team's primus inter pares was Hal Broxmeyer; Lewis Thomas provided the public face; Rodman Rockefeller supplied the initial funding; and Bo Dupont acted as advi- sor. Many others contributed. Eliane Gluckman, at the Hôpital SaintLouis in Paris, embraced the challenge of performing the world's first clinical cord-blood transplant with alacrity and complete success. The patient, a young boy with Fanconi anemia who was treated in 1988 with cord blood taken from his sister, remains in good health.

Shepherding these diverse programs occupied Boyse until his preretirement move to the University of Arizona at Tucson. There he instituted cord-blood programs, energetically espoused by others, and continued to share his thoughts with junior investigators until his full retirement in 1994.

Edward Arthur Boyse was born in Worthing, Sussex, on August 11, 1923, the third of four children of Arthur Boyse, Fellow of the Royal College of Organists, and Dorothy Vera Boyse, née Mellersh. Boyse acquired his love of classical music in the cradle, which was usually lodged under his father's piano, and he served as an altar boy in the church where his father was organist. Musical appreciation in adult life was shared with his children, who reciprocated by introducing him to the Beatles.

Boyse was an independent child who relished long bicycle rides and constructing model theaters for which he wrote and produced plays. The former continued throughout his life; the latter reached fruition in his student days, when his performance as an Ugly Stepsister garnered rave reviews in newspaper articles still preserved.

His interests in retirement leaned towards the physical; he was an active man throughout his life and took pleasure in running and long walks in the desert. Boyse never considered himself an intellectual or an academic. The individuals with whom he chose to share friendship were few and steadfast and had in common with him the traits of enthusiasm, joy and mischief.

Boyse is survived by his wife, Judith Bard, his children Conrad Boyse and Dr. Adrienne Martin (with his first wife Jeanette), and five grandchildren.

He is also survived by his many students. In the words of Ellen Goldberg:

Ted was, by far, ahead of the curve when it came to developing new ideas and programs. Others would follow his lead. Not only were his scientific contributions and ideas brilliant but he openly shared these thoughts with students and colleagues.

He was an extremely kind person with a wonderful sense of humor, so even as a student, I was comfortable discussing my thoughts with him. It was Ted who opened up the world for me, not just scientifically, but broadening my interests through literature and friendship. He was such a great man. 